\title{
Arminius, Arminian, dan Kaum Injili: Sebuah Klarifikasi
}

\author{
Marlon Lahope \\ Program Studi Magister Teologi Sekolah Tinggi Teologi SAAT, Malang \\ Korespondensi: marlon.lahope@yahoo.co.id
}

\begin{abstract}
Abstrak: Tulisan ini akan memberikan klarifikasi terhadap tuduhan-tuduhan palsu yang sering dilontarkan sebagian besar kaum Calvinis kepada kaum Arminian dan kemudian mendiskusikan alasan utama kaum Arminian menolak ajaran Calvinisme. Klarifikasi ini akan difokuskan pada dua tuduhan yang sering menjadi kartu favorit, yakni Arminianisme menolak konsep kerusakan total dan mengajarkan manusia sebagai penentu keselamatannya. Jawaban terhadap tuduhan ini sederhana, kedua tuduhan ini adalah hasil dari pembacaan yang keliru atau representasi yang cacat terhadap teologi Arminian. Setelah itu, penulis akan mendiskusikan alasan utama penolakan kaum Arminian terhadap ajaran Calvinisme, yakni konsep kedaulatan Allah Calvinisme membawa logika kepada konsekuensi yang sulit dihindari bahwa Allah adalah sumber dari segala dosa. Di sisi yang lain, tulisan ini tidak dimaksudkan untuk melebarkan jurang pemisah dalam tubuh kaum Injili. Sebaliknya, kaum Injili harus melihat perbedaan sebagai keragaman dalam tubuh Kristus daripada menjadikannya sebagai pemicu keterpecahan. Di tengah perbedaan yang ada, injil haruslah menjadi prioritas utama dan bukan perdebatan-perdebatan minor yang akhirnya hanya menghambat pemberitaan injil Yesus Kristus.
\end{abstract}

Kata-kata kunci: Arminian(isme), Calvinis(isme), Kerusakan Total, Keselamatan karena Anugerah, Kedaulatan Allah, Injili

Abstract: This article will provide clarification of the false accusations that most Calvinists often make to the Arminians and then discuss the main reasons Arminians reject the teachings of Calvinism. This clarification will focus on two accusations that are often favorite cards, namely Arminianism rejects the concept of total depravity and teaches that human as a determinant factor of their salvation. The answer to these accusations is simple, these two accusations are the result of a false reading or defective representation of Arminian theology. After that, the author will discuss the main reason why the Arminians reject the teachings of Calvinism, namely the concept of God's sovereignty in Calvinism brings logic to the inevitable consequences that God is the source of all sins. On the other hand, this article is not intended to widen the gap in the body of the evangelical. Conversely, evangelicals must see the differences as diversity in the body of Christ rather than making it a trigger for division. In the midst of differences, the gospel must be a top priority and not minor debates which ultimately only hinder the preaching of the gospel of Jesus Christ.

Keywords: Arminian(ism), Calvinis(m), Total Depravity, Salvation by Grace, Sovereignty of God, Evangelical 


\section{PENDAHULUAN}

Mengejutkan jika perdebatan antara Calvinis dan Arminian masih sepanas empat ratus tahun yang silam. Sejarah telah memberikan catatan yang melimpah bahwa perdebatan ini sudah menghasilkan banyak sekali perpecahan dan permusuhan dalam gereja yang malah menjadi batu sandungan bagi injil Yesus Kristus. Sebagai kaum Injili, sebelum kita memperdebatkan isu-isu teologis, apa pun itu, mungkin kita harus berhenti sejenak untuk merenung dan bertanya: "Apakah perdebatan ini akan memberi dampak positif bagi pemberitaan injil atau hanya menjadi dinding penghalang bagi orang-orang untuk melihat Kristus di dalam Kristen?" atau, "Akankah gereja semakin bersatu ataukah malah akan terus saling melukai?" Beberapa teolog kontemporer telah bergerak lebih maju dengan menekankan common ground dalam gerakan Protestan daripada mencari perbedaannya dan kemudian saling menjatuhkan. ${ }^{1}$ Sementara yang lain, sibuk mencari atau membicarakan kesalahan dan menciptakan permusuhan. Terhadap mereka yang gemar melebarkan perbedaan dan menciptakan permusuhan dalam tubuh Kristus, khususnya di dalam tubuh kaum Injili, tepatlah jika mengutip ucapan Yesus, "Pergilah, dan jangan berbuat dosa lagi mulai dari sekarang" (Yoh. 8:11).

Namun, memang tidak jarang kita diperhadapkan dengan dilema akademik. Beberapa orang entah sengaja atau tidak, menuduh teolog atau kaum tertentu dengan tuduhan yang palsu atau keliru. Hal seperti ini tentu harus direspons, namun bukan sebagai ajakan untuk berdebat atau merangsang permusuhan, tetapi merupakan sebuah klarifikasi demi diskusi teologis yang sehat, objektif, dan jujur. Inilah alasan utama dari keberadaan karya ini, yakni demi sebuah klarifikasi. Dalam tulisan ini penulis akan memberikan beberapa klarifikasi mengenai tuduhan-tuduhan palsu

${ }^{1}$ Misalnya, Kevin J. Vanhoozer, Biblical Authority: Retrieving the Solas in the Spirit of Mere Christianity (Grand Rapids: Brazos, 2016), 1-34 dan Kevin J. Vanhoozer dan Daniel J. Treier, Theology and the Mirror of Scripture: $A$ Mere Evangelical Account (London: Apollos, 2016), 19-44. yang beredar tentang teologi Arminian..$^{2}$ Ada banyak sekali tuduhan palsu yang beredar dan kemudian menciptakan stigma negatif mengenai Arminianisme. Namun, karena keterbatasan halaman, penulis hanya akan mendiskusikan beberapa yang penting saja. Pertama, penulis akan membahas mengenai tuduhan bahwa Arminianisme menolak konsep kerusakan total. Kedua, penulis akan merespons tuduhan yang mengatakan bahwa Arminianisme mengajarkan keselamatan merupakan usaha manusia. Setelah itu, penulis akan mendiskusikan alasan utama mengapa kaum Arminian memilih untuk menjadi Arminian daripada menganut Calvinisme. Beberapa orang mengatakan bahwa kaum Arminian menolak Calvinisme hanya karena ingin mempertahankan kehendak bebas manusia, ${ }^{3}$ namun dalam tulisan ini penulis akan memberikan tanggapan bahwa pada hakikatnya tuduhan tersebut salah sasaran.

\section{SEKILAS TENTANG JAMES ARMINIUS DAN KONFLIK DI LEIDEN}

Terminologi Arminianisme berasal dari nama seorang teolog Belanda, James Arminius, yang lahir tahun 1560 dan meninggal dunia pada tahun $1609 .{ }^{4}$ Pada usia lima belas tahun Arminius dikirim ke Jerman untuk belajar. Kemudian ia melanjutkan studinya di Universitas Leiden. Karena prestasi akademik yang gemilang, gereja Reformed di Amsterdam membiayai studinya selama ia belajar di Leiden sampai ia melanjutkan pendidikannya di Swiss. Di Swiss inilah Arminus belajar tentang

\footnotetext{
${ }^{2}$ Sebenarnya beberapa teolog Arminian telah memberikan klarifikasi terhadap tuduhan-tuduhan palsu yang beredar. Misalnya, dua belas tahun yang lalu pakar sejarah teologi Kristen, Roger Olson, menulis salah satu buku yang sangat baik berjudul Arminian Theology: Myths and Realities (Downers Grove: IVP, 2006). Juga F. Leroy Forlines, Classical Arminian: A Theology of Salvation (Nashville: Randall House, 2011). Namun, jarang sekali klarifikasi-klarifikasi ini didiskusikan atau tersampaikan, khususnya di Indonesia.

${ }^{3}$ Misalnya, Edwin H. Palmer, Lima Pokok Calvinisme, terj. Elsye (Surabaya: Momentum, 2011), 45 dan Paul Helm, "Classical Calvinist Doctrine of God," dalam Perspectives on the Doctrine of God, ed. Bruce A. Ware (Nashville: B\&H Academic, 2008), 7.
}

${ }^{4}$ Olson, Arminian Theology, 13. 
Calvinisme di bawah asuhan Theodore Beza, seorang tokoh Calvinis yang skolastik, juga menantu John Calvin. ${ }^{5}$

Setelah menyelesaikan studinya di Swiss, Arminius mulai melakukan kritik secara terbuka kepada Calvinisme, baik aliran supralapsarian ataupun infralapsarian. ${ }^{6}$ Penting untuk diketahui bahwa penolakan terhadap konsep predestinasi John Calvin tidak hanya datang dari Arminius saja, selain mendapat kritikan tajam dari gereja Katolik Roma saat itu. Penolakan-penolakan ini sebenarnya muncul dari beberapa teolog Reformed yang lain, misalnya Sebastian Castellio, yang akibat penolakannya ia diusir dari Jenewa, ${ }^{7}$ atau Jerome Bolsec, tepat ketika ia datang ke Jenewa tahun 1550 , ia langsung melancarkan serangan terhadap konsep predestinasi Calvin dan cenderung sependapat dengan tokoh-tokoh reformasi seperti, Melanchthon, Brenz, dan Bullinger. ${ }^{8}$ Beberapa contoh penolakan-penolakan ini cukup untuk menjelaskan kepada kita bahwa predestinasi yang digadang Calvin tidak mendapatkan penerimaan yang monolit. ${ }^{9}$ Dengan kata lain, Calvinisme saat itu bukanlah

\footnotetext{
${ }^{5}$ Roger E. Olson, The Story of Christian Theology: Twenty Centuries of Tradition and Reform (Downers Grove: IVP, 1999), 461. Dalam sejarah teologi Beza juga dikenal sebagai salah satu pencetus tipe teologi Calvinisme yang ekstrem yang dikenal dengan supralapsarian (Ibid., 456).
}

${ }^{6}$ Terdapat wacana bahwa Arminius sebelumnya adalah seorang Calvinisme supralapsarian. Namun, sarjana Arminius yang terkenal, Carl Bangs, mengatakan bahwa semua bukti yang ada malah mengasumsikan sebaliknya. Menurut Bangs, selama Arminius belajar teologi di bawah Beza, ia tidak pernah sependapat dengan Beza (Carl Bangs, Arminius: A Study in the Dutch Reformation [Grand Rapids: Zondervan, 1985], 144).

${ }^{7}$ Carl Bangs, "Arminius and the Reformation," Church History 30, no. 2 (Juni: 1961): 157.

${ }^{8}$ Bangs, "Arminius and the Reformation," 157. Belakangan ketika Bullinger menulis The Second Helvetic Confession tahun 1562, ia menyisipkan artikel yang mengafirmasi predestinasi atau pemilihan ilahi, meskipun tanpa membahas mengenai reprobasi (Ibid., 158).

${ }^{9}$ Bahkan Richard Muller mengakui adanya penolakan atau perbedaan pendapat mengenai konsep predestinasi Calvin saat itu dalam gerakan Reformasi atau Protestan. Lihat Richard A. Muller, "Arminius and the Reformed Tradition," dalam The Westminster Theological Journal 70, no. 1 (Spring, 2008): 40. satu-satunya ajaran Reformed, namun bagian dari gerakan Reformasi yang besar. ${ }^{10}$

Ada banyak alasan mengapa Arminius menolak konsep predestinasi yang digadang oleh Calvin. Beberapa di antaranya adalah konsep ini tidak diterima atau diajarkan dalam konsili-konsili gereja ekumenis, seperti Konsili Nicea, Konsili Konstantinopel yang pertama sampai yang ketiga, Konsili Efesus, dan Konsili Kalsedon. ${ }^{11}$ Selain itu, konsep ini tidak diajarkan oleh Bapa-bapa gereja sampai enam ratus tahun setelah kebangkitan Yesus. Sejarah mencatat bahwa perdebatan antara Agustinus dan Pelagius tidak pernah membuat gereja mengafirmasi dan mengajarkan predestinasi, meskipun ajaran Pelagius bahwa manusia terlahir sebagai kertas putih dikutuk sebagai bidah dalam Konsili Efesus. ${ }^{12}$ Namun, ada satu kritikan Arminius yang sangat tajam kepada Calvin. Menurutnya, konsep predestinasi Calvin yang mengatakan bahwa segala sesuatu telah ditetapkan Allah, termasuk segala dosa dan kejahatan, membuat Allah sebagai penyebab dosa, bahkan Allah adalah satu-satunya Pribadi yang berdosa. ${ }^{13}$

Sekitar tahun 1590 perdebatan antara Arminius dan teolog-teolog Calvinis yang kaku berkembang menjadi sebuah konflik. ${ }^{14}$ Salah satu pemicu utamanya adalah ketika Arminius diteguhkan sebagai profesor teologi

${ }^{10}$ Bangs, "Arminius and the Reformation," 155-170. Pembahasan Bangs dalam artikel ini dapat menjadi semacam pendahuluan yang baik mengenai letak konsep predestinasi Calvin pada masa Reformasi dan bagaimana konsep ini direspons secara berbeda oleh gereja Reformed saat itu. Lihat juga Olson, Arminian Theology, 44-47.

${ }^{11}$ James Arminius, The Works of James Arminius, ed. Jon Van Hofwegen (Grand Rapids: Christian Classics Ethreal Library, 2002), 1:123.

${ }^{12}$ Ibid. Penting untuk dicatat bahwa Konsili Efesus tahun 431 memang mengutuk ajaran Pelagius tetapi juga tidak menerima dan mengajarkan doktrin predestinasi yang digadang Agustinus. Lucunya, sebagian pendukung Agustinus menafsirkan hasil konsili mengafirmasi predestinasi Agustinus (lih. Olson, The Story of Christian Theology, 268).

${ }^{13}$ Ibid.,125-126, 130.

${ }^{14}$ Robert A. Peterson dan Michael D. Williams, Why I Am Not an Arminian (Downers Grove: IVP, 2004), 99. 
di Universitas Leiden tahun 1603 dan bertemu dengan Franciscus Gomarus, seorang Calvinis supralapsarian, juga sebagai profesor teologi di universitas yang sama. Tidak lama setelah Arminius menjabat sebagai profesor teologi, Gomarus mulai melakukan kampanye untuk melawan Arminius. ${ }^{15}$ Kontroversi atau perdebatan ini memuncak dan akhirnya menciptakan perang warga sipil antarprovinsi di Belanda. ${ }^{16}$ Pada tahun 1609 di tengah penyelidikan mengenai konflik yang ada oleh otoritas gereja dan pemerintah, Arminius meninggal dunia akibat penyakit tuberkulosis yang dideritanya. Di acara pemakamannya seorang sahabat dekatnya menyampaikan eulogi yang mengharukan, "There lived in Holland a man whom they who did not know could not sufficiently esteem, whom they who did not esteem had never sufficiently known."17

\section{ARMINIAN DAN FITNAH TENTANGNYA}

Ada banyak tuduhan palsu yang beredar mengenai Arminianisme. Dalam bukunya Arminian Theology, Olson membahas kurang lebih sembilan tuduhan palsu. Namun, karena keterbatasan halaman maka dalam tulisan ini penulis hanya akan mendiskusikan beberapa tuduhan yang paling populer saja, atau yang paling sering digunakan sebagai kartu favorit oleh sebagian teolog Calvinis ketika mendiskusikan Arminianisme, yakni Arminianisme menolak konsep kerusakan total dan mengajarkan bahwa keselamatan adalah usaha manusia.

\section{Arminian dan Kerusakan Total: Antropologi yang Optimistik?}

Henry C. Thiessen dalam salah satu karyanya menuliskan bahwa bagi kaum Arminian akibat dosa Adam dan Hawa terhadap keturunannya hanya sampai pada kondisi sakit saja dan bukan mati atau rusak secara total. Ia menambahkan, ketidakmampuan

\footnotetext{
${ }^{15}$ Olson, The Story of Christian Theology, 462 dan Peterson dan Williams, Why I Am Not An Arminian, 100.

${ }^{16}$ Ibid., 463.

${ }^{17} \mathrm{Ibid}$.
}

ini bersifat fisik dan intelektual saja. ${ }^{18}$ Stuart Picken dengan gamblang mengatakan, Arminianisme menolak konsep kerusakan total dan dosa asal. ${ }^{19}$ Robert Letham dalam pemaparannya mengenai Arminianisme mengatakan bahwa menurut kaum Arminian manusia yang berdosa masih memiliki kehendak bebas. Bahkan, ia menuduh kaum Arminian memperkenalkan ajaran semipelagian. ${ }^{20}$ Senada dengan teolog-teolog sebelumnya, Edwin Palmer, mengatakan bahwa menurut Arminianisme "manusia yang belum diselamatkan (masih berdosa) dengan kekuatannya sendiri, dengan pertolongan Roh Kudus, berkemampuan untuk meminta kepada Yesus untuk menyelamatkan dia." 21

Daftar tokoh Calvinisme yang melemparkan tuduhan yang serupa masih bisa terus bertambah. Namun, beberapa teolog papan atas yang telah disebutkan tadi tentu dapat mewakili dan menjelaskan kepada kita bahwa tuduhan itu menjalar dan berjangkit dalam pemikiran rekan-rekan Calvinis. Untuk menjawab tuduhan-tuduhan ini kita harus membaca sumber-sumber yang ditulis oleh kaum Arminian sendiri. Mereka yang mencari jawaban pada lembar-lembar buku yang ditulis oleh kalangan Calvinis sangat mungkin terjebak dalam kekeliruan komunal yang telah membudaya sampai hari ini. Jadi, apakah Arminianisme menolak konsep kerusakan total?

Teolog Aminian, F. Leroy Forlines, mengatakan dengan tegas bahwa sangatlah jelas jika Alkitab mengajarkan manusia jatuh dari kondisi kudus kepada kondisi yang penuh dosa (Yes. 53:6; Rm. 3:23). Sangatlah jelas bahwa manusia yang berdosa tidak mampu untuk

${ }^{18}$ Henry C. Thiessen, Teologi Sistematika (Malang: Gandum Mas, 2010), 286. Lihat juga, Paul Enns, The Moody Handbook of Theology: Buku Pegangan Teologi 2, terj. Rahmiati Tanudjaja (Malang: Literatur SAAT, 2010), 131.

${ }^{19}$ Stuart Picken, Historical Dictionary of Calvinism (Lanham: Scarecrow, 2012), 32.

${ }^{20}$ Robert Letham, "Arminianism," dalam Encyclopedia of the Reformed Faith, ed. Donald K. McKim (Louisville: WJK, 1992), 11.

${ }^{21}$ Palmer, Lima Pokok Calvinisme, 18. 
menyenangkan Allah (Ef. 2:1-3; Rm. 8:7-8). Sangatlah jelas bahwa manusia tidak mampu datang kepada Allah tanpa kuasa Roh Kudus yang menariknya (Yoh. 6:44). ${ }^{22}$ Kemudian Forlines menyimpulkan pernyataannya mengenai kerusakan total yang dipahami Arminianisme demikian, "In summary total means that the corruption has extended to all aspects af man's nature, to his entire being; and depravity means that, because of that corruption, there is nothing man can do to merit saving favor with God." 23 Forelines dengan jelas menegaskan bahwa Arminianisme mengafirmasi konsep kerusakan total yang disebabkan oleh dosa.

Senada dengan Forelines, Roger Olson, menekankan bahwa Arminianisme sependapat dengan Calvinisme dalam menerima konsep kerusakan total yang disebabkan oleh kejatuhan manusia melalui Adam. Arminian percaya akan kerusakan total yang menyebabkan setiap aspek dari natur manusia dicemari oleh dosa. ${ }^{24}$ Teolog Wesleyan, William Greathouse dan Ray Dunning, dengan jelas mengatakan bahwa "our natural inheritance (dari Adam) is death and sin." ${ }^{25}$ Dalam kondisi ini manusia bukan hanya tidak mampu menyenangkan Allah, namun tanpa anugerah Allah manusia tidak memiliki kehendak bebas, satu-satunya kebebasan yang dimiliki manusia adalah berbuat dosa. ${ }^{26}$ John Wesley, salah satu tokoh Arminian yang paling berpengaruh dalam sejarah kekristenan mengatakan:

After all that has been so plausibly written concerning "the innate idea of God"; after all that has been said of its being common to all men, in all ages and nations; it does not appear, that man has naturally any more idea of God than any of the beasts of the field; he has no knowledge of God at all; no

${ }^{22}$ Forlines, Classical Arminian, 16.

${ }^{23}$ Ibid., 17.

${ }^{24}$ Olson, Arminian Theology, 55-56.

${ }^{25}$ William M. Greathouse dan H. Ray Dunning, $A n$ Introduction to Wesleyan Theology (Kansas City: Beacon Hill, 1989), 56.

${ }^{26}$ Ibid. fear of God at all; neither is God in all his thoughts. Whatever change may afterwards be wrought, (whether by the grace of God, or by his own reflection, or by education, ) he is, by nature, a mere Atheist. ${ }^{27}$

Wesley dengan senang hati menerima konsep kerusakan total seperti yang dipercaya oleh Calvinisme, bahkan mungkin dengan deskripsi yang lebih radikal.

James Arminius sendiri dengan gamblang mengatakan bahwa dalam statusnya yang berdosa manusia tidak memiliki kemampuan dari dirinya sendiri untuk berpikir, atau menginginkan, atau melakukan apa pun yang baik. ${ }^{28}$ Menurut Arminius, dalam kondisi ini kehendak bebas manusia untuk melakukan kebaikan yang sesungguhnya, bukan hanya terluka, lumpuh, lemah, cacat, atau tak berdaya tetapi terpenjara, hancur, dan hilang. Manusia takkan mampu melakukan apa-apa tanpa anugerah dari Allah. ${ }^{29}$

Jadi, apakah kaum Arminian menolak kon-

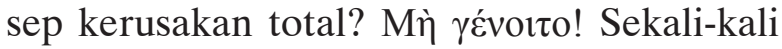
tidak. Jelaslah bahwa tuduhan yang selama ini beredar dan yang dipelihara dengan manja, bahwa Arminian menolak konsep kerusakan total adalah kesalahan total. ${ }^{30}$ Tepat seperti yang diakui oleh teolog Calvinis sendiri, Michael Horton, bahwa adalah sebuah karikatur jika kita berpikir kaum Arminian

${ }^{27}$ John Wesley, dalam William J. Abraham, Aldersgate and Athens: John Wesley and the Foundation of Christian Belief (Waco: Baylor University Press, 2010), 25-26.

${ }^{28}$ Arminius, The Works of James Arminius, 2:144.

${ }^{29}$ Ibid., 1:312-313.

${ }^{30}$ Memang sebagian teolog yang mengaku sebagai kaum Arminian menolak konsep kerusakan total. Misalnya, Charles Finney yang menerima kemampuan moral manusia dalam hal spiritual tanpa topangan anugerah Allah (Charles Finney, Finney's Systematic Theology, ed. J.H. Fairchild [Minneapolis: Bethany Fellowship, 1976], 261, 299). Namun, telah didiskusikan di atas bahwa Arminius dan para pengikutnya dengan tegas mengafirmasi kerusakan total yang disebabkan oleh dosa, maka tidak mungkin untuk meletakkan Finney dalam tradisi Arminian. Posisi Finney sejajar dengan ajaran semi-Pelagianisme atau bahkan Pelagianisme daripada Arminianisme atau Calvinisme yang memegang teguh konsep kerusakan total. 
menolak kerusakan total manusia yang disebabkan oleh dosa. ${ }^{31}$

\section{Arminian dan Keselamatan: Semua karena Aku?}

Sebagai konsekuensi dari tuduhan palsu yang telah dibahas di atas, maka wajar saja jika sebagian besar teolog Calvinis menyimpulkan bahwa kaum Arminian mengajarkan keselamatan sebagai hasil dari usaha manusia. Misalnya, Edwin Palmer, memberikan ilustrasi mengenai konsep keselamatan menurut Arminian demikian:

Kepalanya timbul tenggelam di dalam air sementara ia menggapai-gapaikan tangannya, berusaha untuk tidak tenggelam. Bila tidak ada orang yang menyelamatkannya, ia akan mati. Mungkin paru-parunya sudah kemasukan air, mungkin ia sempat pingsan sebentar, tetapi ia masih dapat berpikir dan masih mampu melambai serta menjerit kepada pengawas pantai agar diselamatkan. Bila ia berseru kepada pengawas pantai, maka pengawas pantai itu akan menyelamatkan dia. ${ }^{32}$

Melalui ilustrasi ini Palmer ingin menekankan bahwa Arminianisme mengajarkan keselamatan sebagai usaha manusia. ${ }^{33}$

James Montgomery Boice melantunkan tuduhan yang sama. Ketika mendiskusikan mengenai topik keselamatan sebagai anugerah semata, ia menyindir kaum Arminian dengan mengatakan bahwa mereka ingin memuliakan Allah, tentu mereka bisa mengatakan "kemuliaan bagi Allah," meski demikian mereka tidak boleh mengatakan "kemuliaan hanya bagi Allah," karena mereka menekankan kekuatan manusia atau kemampuan manusia dalam merespons injil

${ }^{31}$ Michael Horton, The Christian Faith: A Systematic Theology for Pilgrims on the Way (Grand Rapids: Zondervan, 2011), 565.

${ }^{32}$ Palmer, Lima Pokok Calvinisme, 16.

${ }^{33}$ Ibid., 18, 32, 45. anugerah. ${ }^{34}$ Boice melanjutkan sindirannya dengan mengatakan bahwa di surga nanti seorang Arminian bisa menyombongkan diri dan berkata, "Aku memilih untuk percaya. Aku, dengan kekuatanku, menerima Yesus Kristus sebagai Juruselamat." 35

Daftar nama teolog yang melayangkan tuduhan ini dapat terus bertambah. ${ }^{36}$ Namun, Palmer dan Boice cukup untuk menjadi rujukan jika sebagian kaum Calvinis menuduh bahwa Arminianisme memiliki konsep keselamatan yang memberikan penekanan kepada usaha manusia. Manusialah penentu ultimat keselamatan mereka dan bukan anugerah Allah. Semua karena aku (manusia)!

Tuduhan ini sebenarnya telah terjawab bersama dengan pembahasan mengenai tuduhan pertama di atas. Jika Arminianisme memercayai konsep kerusakan total, bahwa kejatuhan manusia dalam dosa menyebabkan manusia mati-bukan hanya sekadar terluka parah atau sekarat, seperti anggapan beberapa teolog Calvinis-maka tentu manusia tidak mampu menyelamatkan dirinya sendiri, karena manusia mati dalam dosa. Arminius menekankan dengan tegas bahwa dalam kondisi berdosa ini kehendak bebas manusia bukan hanya terluka, lumpuh, lemah, cacat, atau tak berdaya, tetapi terpenjara, hancur, dan hilang. Dengan demikian, segala kemungkinan yang membuat manusia mampu melakukan sesuatu untuk menyelamatkan dirinya sirna karena dosa telah menguasai seluruh aspek hidup manusia. Artinya, kaum Arminian dengan segenap hati mengimani bahwa keselamatan seutuhnya dan sepenuh-penuhnya adalah anugerah Allah.

\footnotetext{
${ }^{34}$ James Montgomery Boice, Whatever Happened to the Gospel of Grace?: Rediscovering the Doctrines that Shook the World (Wheaton: Crossway, 2001), 167. Penekanan sesuai aslinya.

${ }^{35}$ Ibid.

${ }^{36}$ Mis. Herman Bavinck, Reformed Dogmatics: Abridged in One Volume, ed. John Bolt (Grand Rapids: Baker Academic, 2011), 252; Letham, "Arminianism," 11; dan Picken, Historical Dictionary of Calvinism, 32.
} 
Pakar Perjanjian Baru, I. Howard Marshall, yang juga adalah seorang Arminian dengan tegas mengatakan:

In every case it is God who takes the initiative in salvation and calls men to him, and works in their hearts by his Spirit. Salvation is never the result of human merit, nor can anybody be saved without first being called by God. Men cannot in any sense save themselves. It must be declared quite emphatically that the non-Calvinist affirms this as heartily as the Calvinist and repudiates entirely the Pelagianism which is often (but wrongly) thought to be inherent in his position. When a person becomes a Christian, he cannot do anything else but own that it is all of grace. ${ }^{37}$

Poin Marshall sangat jelas, Arminianisme percaya bahwa Allah yang berinisiatif untuk menyelamatkan dan memanggil manusia. Keselamatan bukanlah hasil usaha manusia, namun pekerjaan Allah melalui Roh Kudus yang bekerja dalam hati manusia. Keselamatan semata-mata adalah anugerah Allah. Hal ini ditekankan juga ratusan tahun yang lalu oleh John Wesley dengan mengatakan bahwa apa pun yang baik dalam diri manusia (termasuk keselamatan) atau dilakukan oleh manusia, Allah adalah penulisnya, Allah adalah pelakunya. ${ }^{38}$

James Arminius sendiri mengajarkan hal ini dengan gamblang. Ia mengatakan:

It is a gratuitous affection by which God is kindly affected towards a miserable sinner, and according to which he, in the first place, gives his Son, "that whosoever believers in him might have eternal life," and, afterwards, he justifies him in Christ Jesus and for his sake, and adopts him into the right of sons, unto salvation. It is an infusion (both into the human understanding and into the will and affections, ) of all those gifts of the Holy

${ }^{37}$ I. Howard Marshall, "Predestination in the New Testament," dalam Grace Unlimited, ed. Clark H. Pinnock (Minneapolis: Bethany Fellowship, 1975), 49. Penekanan sesuai aslinya.

${ }^{38}$ John Wesley, The Works of John Wesley, ed. Albert C. Outler (Nashville: Abingdon, 1986), 3:545.
Spirit which appertain to the regeneration and renewing of man-such as faith, hope, charity, etc.; for, without these gracious gifts, man is not sufficient to think, will, or do anything that is good. ${ }^{39}$

Penegasan Arminius adalah keselamatan sepenuh-penuhnya merupakan anugerah Allah. Allah melalui Roh Kudus memampukan manusia untuk merespons injil keselamatan yang dikerjakan oleh Yesus Kristus dengan sempurna dan tak bercacat. Bagi Arminius, sangat jelas bahwa tindakan iman atau respons terhadap injil hanya dapat bekerja melalui anugerah Allah. ${ }^{40}$ Allah yang memberikan anugerah melalui karya Roh Kudus di dalam diri manusia. Dengan demikian, menurut Arminius,

Evangelical faith is an assent of the mind, produced by the Holy Spirit, through the gospel, in sinners, who, through the law, know and acknowledge their sins, and are penitent on account of them, by which they are not only fully persuaded within themselves that Jesus Christ has been constituted by God the author of salvation to those who obey him, and that he is their own saviour if they have believed in him, and by which they also believe in him as such, and through him on God as the benevolent Father in him, to the salvation of believers and to the glory of Christ and God. ${ }^{41}$

Dengan demikian, tepat seperti yang disimpulkan oleh sarjana Arminius, Keith Stanglin, "In sum, humanity is totally unable to be saved without God's grace."42

Karena itu, kaum Calvinis yang masih memiliki pemahaman yang keliru mengenai Arminianisme harus berhenti melontarkan

\footnotetext{
${ }^{39}$ Arminius, The Works of James Arminius, 1:144-145. Penekanan dari penulis.

${ }^{40}$ Ibid., 2:78.

${ }^{41}$ Ibid., 2:84.

${ }^{42}$ Keith Stanglin, Arminius on the Assurance of Salvation: The Context, Roots, and Shape of the Leiden Debate, 1603-1609 (Boston: Brill, 2007), 82. Penekanan dari penulis.
} 
tuduhan-tuduhan palsu yang telah didiskusikan di atas. Hal ini tentu demi objektivitas, kejujuran, dan kedewasaan dalam berteologi. Meski demikian, dari diskusi ini muncul pertanyaan yang lain. Jika Calvinisme dan Arminianisme sama-sama mengafirmasi kerusakan total dan keselamatan sepenuhnya adalah anugerah Allah, seharusnya tidak ada lagi perbedaan yang signifikan antara teologi Calvinisme dan Arminianisme, karena perdebatan selama ini sangat dipengaruhi oleh dua tuduhan palsu di atas. Lantas, apa yang menjadi masalah utama atau keberatan utama James Arminius atau kaum Arminian terhadap penolakan mereka yang tegas terhadap teologi Calvin atau Calvinisme? Diskusi dalam subbab selanjutnya akan memberikan jawaban terhadap pertanyaan ini.

\section{ANTARA KEDAULATAN ALLAH DAN KEBABLASAN CALVINISME}

Poin utama yang membuat James Arminius dan kaum Arminian menolak Calvinisme bukanlah konsep kerusakan total, bukan pula konsep keselamatan yang sepenuhnya adalah anugerah Allah, apalagi hanya demi mempertahankan kehendak bebas manusia. ${ }^{43}$ Namun, tentang ajaran Calvin yang kemudian dipegang dengan teguh oleh Calvinisme, yakni konsep dekrit Allah yang kekal atas segala sesuatu. Secara sederhana ketetapan ilahi ini berarti sebelum dunia dijadikan Allah telah menetapkan segala sesuatu dan segala sesuatu itu pasti terjadi. Dalam kaitannya dengan soteriologi, ketetapan ini mengatakan bahwa sebelum dunia dijadikan Allah telah menetapkan siapa saja yang dipilih-Nya untuk menjadi umat pilihan dan siapa saja yang ditetapkan Allah untuk dibinasakan dalam nereka yang kekal (reprobasi). ${ }^{44}$ Konsep ini

\footnotetext{
${ }^{43}$ Palmer, Lima Pokok Calvinisme, 45.

${ }^{44}$ Beberapa teolog Calvinis memperhalus dengan mengatakan bahwa kaum reprobasi atau mereka yang tidak dipilih Allah adalah mereka yang dilewatkan Allah atau dibiarkan Allah dan bukan ditetapkan Allah. Pernyataan ini bukan hanya cacat secara logika, argumentasi seperti ini butuh harga yang mahal karena harus mengorbankan intelektualitas. Jika sebelum dunia diciptakan, Allah telah menetapkan untuk tidak memilih sebagian orang atau melewatkan sebagian, apakah itu berbeda dengan Allah
}

dapat ditemukan dalam beberapa tulisan teo$\log$ Calvinis, melihat beberapa di antaranya akan menolong kita memahami konsep ini dengan lebih baik.

J.I. Packer, teolog Calvinis yang tersohor, mengatakan, "Alkitab mengajarkan bahwa sebagai Raja, Allah mengatur dan mengendalikan segala sesuatu, termasuk tindakan manusia, sesuai dengan maksud kekal-Nya." 45 Dalam konteks keselamatan, Packer menambahkan bahwa sejak dari kekekalan Allah telah memilih siapa saja yang akan diselamatkanNya. ${ }^{46}$ Menyadari bahaya dari konsep ini yang berpotensi membuat Allah sebagai penyebab segala sesuatu termasuk dosa dan moralitas yang rusak, Packer memberikan penjelasan tambahan. Ia mengatakan, manusia adalah mahluk moral, meski ia dikendalikan oleh Allah. Di sisi yang lain, manusia dikendalikan oleh Allah meski ia juga adalah makhluk moral yang bertanggung jawab atas perbuatannya. ${ }^{47}$ Namun, bagaimana mungkin dua hal ini dapat direkonsiliasi? Bagaimana mungkin jika Allah yang telah menetapkan segala sesuatu termasuk semua tindakan manusia, namun manusia tetap bertanggung jawab atas semua perbuatannya? Menurut Packer kita harus menerima hal ini sebagai "antinomi" yang diwahyukan Allah. ${ }^{48}$ Antinomi berarti, "dua kebenaran yang tampaknya saja tidak bersesuaian." ${ }^{49}$ Meski demikian, Packer terkesan kesulitan dalam memberikan penjelasan mengenai antinomi yang ia maksudkan dan pada dasarnya ia tidak memberikan solusi apa

menetapkan mereka untuk dilemparkan ke dalam neraka yang kekal karena Allah tidak memilih mereka? Konsekuensi dari tidak dipilih berarti ditolak. Apa pun kata yang akan digunakan untuk memperhalus tindakan yang kejam ini tetap saja sulit untuk diterima oleh logika yang sehat apalagi jika disinari dengan terang Alkitab. Pembahasan berikutnya akan memperjelas diskusi ini.

${ }^{45}$ J.I. Packer, Penginjilan dan Kedaulatan Allah, terj. Helda Siahaan (Surabaya: Momentum, 2001), 12. Penekanan oleh penulis.

${ }^{46}$ Ibid., 82.

${ }^{47}$ Ibid., 13.

${ }^{48}$ Ibid.

${ }^{49}$ Ibid., 9. 
pun untuk kontradiksi yang ada, malah hanya mewariskan kerumitan.

R.C. Sproul, apologet Calvinis yang dihormati, ketika ia mengajar mengenai kedaulatan Allah mengutip Westminster Confession of Faith yang berbunyi:

Allah dari segala kekekalan, bertindak berdasarkan kehendak-Nya yang bijaksana dan kudus, dan tanpa perubahan menentukan segala sesuatu akan terjadi. Namun demikian itu sama sekali tidak berarti bahwa Allah adalah penyebab/pencipta dosa, dan penyebab dari kejahatan yang ada dalam kehendak ciptaan. Allah tidak mengambil kemerdekaan dari penyebab kedua, malahan meneguhkannya. ${ }^{50}$

Menariknya, Sproul menambahkan bahwa barang siapa menolak ide ini ia adalah seorang ateis karena ide bahwa Allah menetapkan segala sesuatu pada dasarnya bukanlah ajaran Calvinisme atau kekristenan, namun merupakan suatu keharusan dalam teisme. ${ }^{51}$ Secara tidak langsung, Sproul mengatakan bahwa satu-satunya kekristenan yang benar adalah kekristenan Calvinisme, di luar Calvinisme yang ada hanyalah ateisme. Kristen Katolik, Kristen Ortodoks, atau aliran Kristen lain yang sudah ratusan bahkan ribuan tahun menyembah Yesus dan mengikuti-Nya pada dasarnya adalah ateisme. Mengapa? Karena mereka menolak konsep kedaulatan Allah yang deterministik. Faktanya, konsep kedaulatan Allah versi Calvinis ini tidak muncul sebelum Agustinus mengajarkannya, dan ironinya, konsep ini ditolak oleh Bapa-bapa Gereja Timur, seperti Yohanes Chrysostom dan Yohanes dari Damaskus. ${ }^{52}$ Sproul harus selalu sadar bahwa kekristenan tidak dimulai

${ }^{50}$ R.C. Sproul, Kaum Pilihan Allah, terj. Rahmiati Tanudjaja dan Jenny Wongka (Malang: Literatur SAAT, 2011), 18. Penekanan oleh penulis. Untuk rujukan utuh mengenai $W C F$ dalam bahasa Indonesia, lihat G.I. Williamson, Pengakuan Iman Westminster, terj. Irwan Tjulianto (Surabaya: Momentum, 2012).

${ }^{51}$ Ibid.,15-16. Penekanan oleh penulis.

${ }^{52}$ Dennis W. Jowers, "Introduction," dalam Four Views on Divine Providence, ed. Stanley N. Gundry dan Dennis W. Jowers (Grand Rapids, Zondervan, 2011), 14-15. abad kelima belas pada saat Luther memakukan sembilan puluh lima tesisnya ataupun abad keenam belas pada saat Calvin menyelesaikan Institutio-nya. Kalimat provokatif seperti ini harus dihindari karena berpotensi memecah belah kekristenan daripada menyatukannya.

Lantas, bagaimana Sproul memecahkan konflik antara Allah yang menetapkan segala sesuatu dan manusia yang tetap bertanggung jawab atas dosanya? Menurut Sproul, Allah yang menetapkan segala sesuatu dan di sisi yang lain manusia memiliki kehendak bebas memang terlihat seperti sebuah kontradiksi, namun hal ini hanya di permukaan saja. Pada dasarnya tidaklah demikian. ${ }^{53} \mathrm{Di}$ sisi lain, Sproul mengakui konflik ini memang sangat sulit untuk dijawab atau diterima, meski demikian, ia tetap menegaskan bahwa Allah bukanlah penyebab dosa. ${ }^{54}$ Dengan demikian, senasib dengan Packer, Sproul tidak memberikan solusi apa pun untuk konflik antara konsep Allah yang menetapkan segala sesuatu dan tanggung jawab manusia atas dosa. ${ }^{55}$

\footnotetext{
${ }^{53}$ Sproul, Kaum Pilihan Allah, 34-35. Jika Packer menggunakan antinomi sebagai solusi, Sproul memilih kata paradoks dan kemudian memahami makna antinomi yang diusulkan Packer sebagai paradoks yang ia gunakan. Menurut Sproul, Packer memilih kata "antinomi" dengan mempertimbangkan konteks budaya Inggris yang memakai antinomi tetapi memiliki makna yang sinonim dengan paradoks di Amerika. Menariknya, Packer sepertinya menggunakan antinomi dengan definisi yang diciptakannya sendiri. Faktanya, ia sendiri menolak definisi antinomi yang disajikan oleh kamus singkat Oxford (lih. Packer, Penginjilan dan Kedaulatan Allah, 9).

${ }^{54}$ Ibid., 21.

${ }^{55}$ Michael Horton mencoba memecahkan masalah ini dengan mengatakan bahwa Allah tidak menyebabkan manusia berdosa, tetapi Allah menetapkan untuk mengizinkan dosa terjadi atau dilakukan oleh manusia yang memiliki kehendak bebas (Horton, The Christian Faith, 311-312). Namun, bagaimana mungkin manusia bisa bebas jika Allah telah menetapkan segala sesuatu dari kekekalan? Apa pun usaha untuk melarikan diri dari premis dasar seperti yang ditemukan dalam Pengakuan Iman Westminster bahwa Allah secara aktif telah menetapkan segala sesuatu sebelum dunia dijadikan, sekali lagi segala sesuatu, maka usaha untuk memberikan kehendak bebas kepada manusia hanya akan berujung pada kontradiksi (Lih. Jack W. Cottrell, "The Nature of the Divine Sovereignty," dalam The Grace of God and the Will of Man: A Case for Arminianism, ed. Clark H. Pinnock [Grand Rapids: Academic Books, 1989], 97). Selain itu, jika Allah
} 
Mungkin Edwin Palmer adalah salah satu tokoh Calvinis yang paling konsisten. Ia berpendapat bahwa penetapan sejak semua berarti rencana Allah yang berdaulat, yang dengannya Allah menetapkan semua yang akan terjadi di seluruh alam semesta ini. Baginya, Allah tidak perlu cemas mengenai apa yang akan terjadi karena "Sejak semula Allah telah menetapkan segala sesuatu 'menurut keputusan kehendak-Nya' (Ef. 1:11): gerakan sebuah jari, detak sebuah jantung, tawa ceria seorang gadis, kesalahan seorang juru ketikbahkan dosa." ${ }^{\prime} 6$ Jika teolog-teolog Calvinis yang lain berupaya untuk tidak membuat Allah sebagai penyebab dosa, Palmer seolaholah membusungkan dadanya dan dengan tenang mengatakan: Allah menetapkan segala sesuatu, apa pun itu, termasuk dosa dan kejahatan. Masalah selesai! Setidaknya mengenai bayang-bayang kontradiksi yang menghantui hukum logika.

Terakhir, John Calvin, ketika menyimpulkan topik pemeliharaan Allah, Calvin mengatakan, "To sum up, since God's will is said to be the cause of all things, I have made his providence the determinative principle for all human plans and works, not only in order to display its force in the elect, who are ruled by the Holy Spirit, but also to compel the reprobate to obedience." ${ }^{57}$ Penjelasan Calvin ini sejajar dengan Palmer, atau lebih tepatnya, Palmer membuktikan dirinya sebagai Calvinis yang sejati. Melalui pernyataan ini, Calvin dengan jelas mengatakan bahwa Allah yang mendorong atau

memang menetapkan untuk mengizinkan manusia berdosa, mengapa perizinan ini hanya berkaitan dengan dosa saja namun tidak dengan kebajikan yang terpuji? Bukankah ketetapan untuk mengizinkan manusia berdosa sama saja dengan menetapkan manusia berdosa? Karena, jika Allah tahu bahwa manusia akan berdosa dan dalam hal ini Ia hanya menetapkan untuk mengizinkan dosa, dan tidak menetapkan untuk mengizinkan manusia melakukan sebaliknya, maka tetap saja Allah tidak memberikan pilihan yang lain kepada manusia, selain untuk berdosa. Jika tidak ada pilihan yang lain, maka konsekuensinya adalah Allah yang membuat manusia berdosa.

${ }^{56}$ Palmer, Lima Pokok Calvinisme, 28. Penekanan oleh penulis.

${ }^{57}$ John Calvin, Institutes of the Christian Religion, ed. John T. McNiell, terj. Ford Lewis Battles (Philadelphia: Westminster, 1959), 232. Penekanan dari penulis. bahkan memaksa mereka yang tidak dipilih (reprobasi) untuk taat kepada ketetapanNya. Seperti yang diutarakan Olson bahwa menurut Calvin, dosa atau kejahatan yang dilakukan oleh manusia atau kaum reprobasi (orang-orang ditetapkan untuk dibinasakan) ditetapkan dan dibuat oleh Allah. ${ }^{58}$

\section{“MENYEMBUHKAN" KARAKTER ALLAH: ARMINIAN DAN KEDAULATAN ALLAH}

Penolakan Arminius atau kaum Arminian terhadap Calvinisme bukanlah demi mempertahankan kehendak bebas manusia, seperti yang telah dijelaskan di atas. Bukan pula mempermasalahkan keadilan Allah dalam kaitannya dengan kaum pilihan dan reprobasi. Namun, berkaitan dengan ide mendasar dari teologi Calvinisme mengenai kedaulatan Allah yang pada dasarnya mencederai karakter Allah. Jangan salah paham, semua tradisi Kristen yang ortodoks, baik gereja Katolik, gereja Timur Ortodoks, atau gereja Protestan termasuk Arminianisme, mengimani dengan kuat doktrin kedaulatan Allah. ${ }^{59}$ Seperti yang dikatakan Olson, "Classical Arminianism goes far beyond belief in general providence to include affirmation of God's intimate and direct involvement in every event of nature and history." ${ }^{60}$ Dengan kata lain, Arminianisme percaya bahwa tidak satu pun ciptaan yang mampu memutuskan atau bertindak tanpa penetapan atau perizinan Allah. ${ }^{6}$ Tepat seperti yang dikatakan Arminius bahwa,

I consider Divine Providence to be "that solicitous, continued, and universally present inspection and oversight of God, according to which he exercises a general care over the whole world, but evinces a particular concern for all his [intelligent] creatures without any exception, with the design of preserving and governing them in their own essence,

\footnotetext{
${ }^{58}$ Roger E. Olson, Against Calvinism (Grand Rapids: Zondervan, 2011), 74.

${ }^{59}$ Olson, Against Calvinism, 83.

${ }^{60}$ Olson, Arminian Theology, 116.

${ }^{61}$ Ibid., 117.
} 
qualities, actions, and passions, in a manner that is at once worthy of himself and suitable to them, to the praise of his name and the salvation of believers. ${ }^{62}$

Untuk memperjelas maksud pernyataannya, Arminius menambahkan, "In this definition of Divine Providence, I by no means deprive it of any particle of those properties which agree with it or belong to it; but I declare that it preserves, regulates, governs and directs all things and that nothing in the world happens fortuitously or by chance." ${ }^{63}$ Jelaslah Arminianisme dengan teguh meyakini bahwa "segala sesuatu, yang ada di sorga dan yang ada di bumi, yang kelihatan dan yang tidak kelihatan, baik singgasana, maupun kerajaan, baik pemerintah, maupun penguasa; segala sesuatu (yang) diciptakan oleh Dia dan untuk Dia" (Kol. 1:16), berada di bawah kontrol atau pemerintahan Allah sebagai Raja alam semesta.

Artinya, Calvinisme dan Arminianisme sepakat mengafirmasi kedaulatan Allah. Tetapi, masalahnya tidak terletak pada penerimaan atau penolakan doktrin kedaulatan Allah, namun bagaimana mendefinisikannya. ${ }^{64} \mathrm{Di}$ sinilah letak masalahnya. Bagi kaum Arminian, konsep kedaulatan Allah Calvinisme yang percaya bahwa Allah menetapkan segala sesuatu, menjadikan Allah sebagai penyebab dosa dan segala kejahatan yang mengerikan. Seperti yang dipertanyakan dan dikhawatirkan oleh filsuf dan teolog Kristen yang sangat dihargai, William Lane Craig, bahwa bagaimana mungkin Allah yang Mahakudus itu menetapkan manusia melakukan kejahatan moral? Lebih jauh lagi, bagaimana mungkin manusia yang ditetapkan untuk berdosa itu mempertanggungjawabkan secara moral apa yang dilakukannya, sementara mereka tidak memiliki kontrol atas setiap keputusannya? Konsep kedaulatan Calvinisme (dan

\footnotetext{
${ }^{62}$ Arminius, The Works of James Arminius, 1: 143-144.

${ }^{63}$ Ibid., 1:144.

${ }^{64}$ Cottrell, "The Nature of the Divine Sovereignty," 97.
}

Agustinian) tampaknya mengubah Allah menjadi Iblis. ${ }^{65}$

Inilah masalah utama dari penolakan kaum Arminian terhadap teologi Calvinisme, yakni konsep kedaulatan Allah dalam Calvinisme secara logis mencederai karakter Allah. ${ }^{66}$ Tentu teolog-teolog Calvinis akan menimpali dan menolak kesimpulan ini, namun konsekuensi logis dari konsep kedaulatan yang mereka suguhkan, bahwa Allah yang secara absolut dan tidak bersyarat menetapkan segala sesuatu untuk terjadi sebelum dunia dijadikan, akan menjadi penghancur untuk setiap pembelaan apa pun yang dikemukakan. ${ }^{67}$ Seperti yang ditegaskan Cottrell, bahwa apa pun usaha yang dilakukan teolog-teolog

${ }^{65}$ William Lane Craig, "God Directs All Things: On Behalf of a Molinist View of Providence," dalam Four Views on Divine Providence, ed. Stanley N. Gundry dan Dennis W. Jowers (Grand Rapids, Zondervan, 2011), 91. Meski demikian, penulis tidak sependapat dengan Craig berkaitan dengan solusi yang ditawarkannya dalam menjawab masalah yang timbul dari konflik teologis antara relasi kedaulatan Allah, prapengetahuan Allah, dan kehendak bebas manusia. Posisi Craig yang mengikuti teolog Katolik Yesuit, Lois de Molina (1535-1600) yang menawarkan middle knowledge, memimpin kepada determinisme Calvinistik, dan hal ini jelas tidak kompatibel dengan Arminianisme pada umumnya, termasuk Arminius sendiri (lih. Olson, Arminian Theology, 197).

${ }^{66}$ Olson, Against Calvinism, 83.

${ }^{67}$ Ibid., 83. Misalnya, seperti yang telah disinggung di atas, bahwa sebagian Calvinis mengatakan bahwa berkaitan dengan dosa Allah menetapkan untuk mengizinkan manusia berdosa. Namun, gagasan utama yang dibawa oleh terminologi "mengizinkan" adalah bersyarat atau kondisional, yakni suatu respons yang reaktif. Artinya, bagaimana mungkin suatu penetapan di waktu yang sama tidak bersyarat dan permisif? (Cottrell, "The Nature of the Divine Sovereignty," 105). Kesimpulan ini senada dengan pernyataan Walls dan Dongell, "But if one is a determinist, each event must be understood in light of its connection with events that precede it as well as those that follow it. Even if we grant that God could have determined things in a very different way than he did, the fact remains that for a deterministand this is the crucial point-no event can be seen in isolation from the events that cause it. When this is kept clearly in mind, it's hard to see how Calvinists can speak of any events or choices as being permitted. Seen as isolated choices this may seem plausible. But if God has arranged things in such a way that previous events and choices cause later ones in a deterministic fashion, then the persons involved could not possibly choose differently than they do precisely because of God's intentional activity" (Jerry L. Walls and Joseph R. Dongell, Why I Am Not A Calvinist [Downers Grove: IVP, 2004], 129). 
Calvinis untuk merekonsiliasi kedaulatan Allah dan kehendak bebas manusia akan selalu berujung pada inkonsistensi. ${ }^{68}$ Sulit untuk menghindari Allah sebagai penyebab dari dosa dan kejahatan.

Kritik keras terhadap konsep kedaulatan Allah Calvinisme juga datang dari teolog terkenal, David Bentley Hart. Menurut Hart, teolog-teolog yang memegang konsep kedaulatan Allah dalam Calvinisme mencemarkan kasih dan kebaikan Allah. ${ }^{69}$ Sikap ini keluar dari ketertarikan yang tidak sehat terhadap kedaulatan Allah yang sebenarnya menakutkan. ${ }^{70}$ Lebih jauh, Hart mengatakan:

If indeed there were a God whose true nature-whose justice or sovereignty-were revealed in the death of a child or the dereliction of a soul or a predestined hell, then it would be no great transgression to think of him as a kind of malevolent or contemptible demiurge, and to hate him, and to deny him worship, and to seek a better God than he. ${ }^{71}$

Penekanan Hart sangat jelas, jika sebelum dunia dijadikan Allah telah menetapkan segala sesuatu termasuk dosa dan berbagai kejahatan keji yang menakutkan dan kemudian melemparkan pendosa yang ditetapkanNya ke neraka, maka bukanlah suatu pelanggaran besar jika kita menganggap-Nya sebagai Allah berhati dengki, jahat, dan kemudian membenci-Nya, dan menolak untuk menyembah-Nya, serta mencari Allah yang lebih baik dari-Nya.

\footnotetext{
${ }^{68}$ Cottrell, "The Nature of the Divine Sovereignty," 102-103.

${ }^{69}$ Senada dengan Hart, Craig mengatakan, "It is deeply insulting to God to think that he would create beings that are in every respect causally determined by him and then treat them as though they were free agents, punishing them for the wrong actions he made them do or loving them as though they were freely responding agents" (William Lane Craig, "Response to Paul Kjoss Helseth," dalam Four Views of Divine Providence, ed. Stanley N. Gundry dan Dennis W. Jowers [Grand Rapids, Zondervan, 2011], 62).
}

${ }^{70}$ David Bentley Hart, The Doors of the Sea: Where Was God in the Tsunami? (Grand Rapids: Eerdmans, 2005), 89.

${ }^{71}$ Ibid., 91.
Bahkan, John Loftus, seorang ateis yang cukup vokal, melibatkan diri untuk mengkritisi konsep kedaulatan Allah menurut Calvinisme. Loftus membenarkan apa yang dikatakan teolog Injili, Clark Pinnock, bahwa jangan heran jika ada orang memilih menjadi ateis jika berhadapan dengan konsep kedaulatan yang seperti ini. ${ }^{72}$ Tentu hal ini merupakan sebuah ironi karena ateisme sendiri tidak tertarik dengan konsep kedaulatan Allah menurut Calvinisme. Hal ini berpotensi menjadikan injil bukan lagi sebuah kabar baik tentang kasih Allah yang besar akan dunia ini (Yoh. 3:16) bagi mereka yang tidak percaya, namun sebaliknya, menjadi semacam batu sandungan. Mengapa? Karena konsep ini menyajikan Allah sebagai pemberi anugerah keselamatan, adalah Allah yang sama yang menetapkan segala dosa dan kejahatan.

Doktrin inilah yang menjadi salah satu alasan utama James Arminius untuk menolak konsep kedaulatan yang diajarkan Calvinisme empat ratus tahun yang silam. Konsep kedaulatan Allah yang diajarkan Calvin atau Calvinisme menjadikan Allah sebagai penyebab atau sumber dosa dan segala kejahatan. ${ }^{73}$ Dengan gamblang ia mengatakan:

For I consider it impossible for any art or sophistry to prevent this dogma concerning "such a previous determination" from producing the following consequences: FIRST. It makes God to be the author of sin, and man to be exempt from blame. SECONDLY. It constitutes God as the real, proper and only sinner: Because when there is a fixed law which forbids this act, and when there is such "a fore-determination" as makes it "impossible for this act not to be committed," it follows as a natural consequence, that it is God himself who transgresses the law, since he is the person who performs this deed against

\footnotetext{
${ }^{72}$ John W. Loftus, Why I Became an Atheist: A Former Preacher Rejects Christianity (Amherst: Prometheus, 2012), 218.

${ }^{73}$ Arminius memberikan kurang lebih dua puluh dua alasan mengapa ia menolak predestinasi Calvinisme (sebagai konsekuensi dari konsep kedaulatan Allah yang menetapkan segala sesuatu), lih. Arminius, The Work of James Arminius, 1:129-141.
} 
the law. For though this be immediately perpetrated by the creature, yet, with regard to it, the creature cannot have any consideration of sin; because this act was unavoidable on the part of man, after such "fore-determination" had been fixed. THIRDLY. Because, according to this dogma, God needed sinful man and his sin, for the illustration of his justice and mercy. FOURTHLY. And, from its terms, $\sin$ is no longer $\sin .{ }^{74}$

Arminius dengan jelas menekankan bahwa mustahil bagi Calvinisme untuk menyelamatkan diri dari konsep kedaulatan Allah yang deterministik yang menjadikan Allah sebagai penyebab segala dosa, Allah sebagai satu-satunya pendosa, Allah membutuhkan manusia yang penuh dosa, dan dosa tidak lagi berarti dosa dalam pengertian pelanggaran terhadap perintah Allah karena Allah adalah pelaku utama dari semua dosa dan kejahatan.

Dengan demikian, dapat disimpulkan bahwa dasar utama dari penolakan Arminius atau kaum Arminian terhadap Calvinisme adalah sifat deterministik dalam teologi kedaulatan Allah Calvinisme. Apa yang ingin dipertahankan atau diusahakan Arminius dan kaum Arminian adalah mempertahankan karakter Allah yang dipaparkan dalam Kitab Suci, khususnya berkaitan dengan kasih, keadilan, dan kekudusan Allah. Dengan kata lain, kaum Arminian melihat bahwa konsep kedaulatan Allah Calvinisme "mencemari" karakter Allah yang dipaparkan Alkitab sehingga merasa perlu untuk "ditahirkan."

Lantas bagaimana kaum Arminian mendefinisikan kedaulatan Allah? Pertanyaan ini dapat dijawab secara komprehensif atau secara sederhana. Namun, untuk memberikan jawaban secara komprehensif akan membutuhkan banyak halaman lain yang tentunya tidak memungkinkan untuk dibahas di sini. Karena itu, penulis akan menjawab pertanyaan ini secara sederhana. Studi lebih lanjut terhadap pertanyaan ini dapat dilihat rujukannya pada catatan kaki.

\footnotetext{
${ }^{74}$ Arminius, The Work of James Arminius, 1:185. Penekanan oleh penulis.
}

Seperti yang ditekankan di atas bahwa Arminianisme percaya Allah berdaulat atas segala sesuatu. Tidak ada hal yang terjadi tanpa penetapan atau perizinan Allah. Hal ini senada yang apa yang dikatakan Jack Cottrell, kedaulatan Allah memuat dua kategori, yakni tidak bersyarat (penetapan) dan bersyarat (perizinan Allah). ${ }^{75}$ Berkaitan dengan dosa atau kejahatan, Alkitab berulang kali menekankan bahwa semua dosa dan kejahatan masuk dalam kategori bersyarat dari doktrin kedaulatan Allah. Dalam kategori bersyarat ini kita bertemu dengan konsep "divine-self limitation" atau Allah yang membatasi diriNya. Artinya, dalam relasi Allah-manusia, Allah di dalam kedaulatan-Nya memberikan ruang bagi kehendak bebas manusia. ${ }^{76}$ Melalui kehendak bebas inilah manusia diberikan kemampuan untuk taat kepada Allah atau memalingkan muka dari-Nya dan hidup di dalam dosa. Namun, jika kehendak bebas adalah satu-satunya jalan di dosa dan kejahatan, mengapa Allah memberikan kehendak bebas kepada manusia? C.S. Lewis, apologet Kristen yang terkenal, menjawab pertanyaan ini dengan indah:

\footnotetext{
${ }^{75}$ Cottrell, “The Nature of Divine Sovereignty,” 107.
}

${ }^{76}$ Olson, Against Calvinism, 99-100. Meski demikian, pertanyaan lain akan muncul, "Bagaimana mungkin manusia yang sudah mati dalam dosa masih memiliki kehendak bebas?" Arminianisme percaya bahwa kehendak bebas manusia sepenuhnya adalah anugerah Allah. Teolog-teo$\log$ Arminian menyebut anugerah yang memampukan manusia untuk memiliki kehendak bebas ini dengan "prevenient grace" atau anugerah pendahuluan. Anugerah pendahuluan ini akan memampukan manusia menolak atau menerima injil Kristus. Untuk diskusi lebih jauh mengenai anugerah pendahuluan, lihat W. Brian Shelton, Prevenient Grace: God's Provision for Fallen Humanity (Anderson: Francis Asbury, 2014). Selain itu, konsep anugerah yang dipahami hari ini tidak sesuai dengan konsep anugerah yang dipahami atau diajarkan Paulus dan dunia Yudaisme Bait Suci kedua. Sarjana Paulus yang dihormati, John M.G. Barclay, dalam studinya mengenai konsep anugerah menurut Paulus dan Yudaisme Bait Suci kedua, mengatakan bahwa konsep anugerah yang diajarkan Agustinus, Luther, Calvin, atau tradisi Reformed, asing di telinga dunia Yunani-Romawi. Menariknya, konsep keselamatan dalam bingkai sinergisme atau kerja sama dipahami sebagai anugerah tanpa jatuh dalam Pelagian atau Semi-Pelagian (lih. John M.G. Barclay, Paul and the Gift [Grand Rapids: Eerdmans, 2015]). Lihat juga, Matthew W. Bates, Salvation by Allegiance Alone: Rethinking Faith, Works, and the Gospel of Jesus the King (Grand Rapids: Baker Academic, 2017), 170-172. 
Karena kehendak bebas, meskipun memungkinkan kejahatan, juga merupakan satu-satunya hal yang memungkinkan kasih atau kebaikan atau sukacita apa pun itu menjadi patut dimiliki. Suatu dunia yang terdiri atas automata-atas makhluk-makhluk yang bekerja seperti mesinakan menjadi hampir tidak bernilai untuk diciptakan. ${ }^{77}$

Karena itu, bagi kaum Arminian, divine selflimitation memungkinkan kedaulatan Allah dan kehendak bebas manusia dapat berdampingan tanpa membuat Allah menjadi penyebab segala dosa dan kejahatan atau tanpa berujung pada kontradiksi yang tidak terselesaikan. Namun, apakah Allah menjadi tidak berdaulat ketika manusia memiliki kehendak bebas? Tentu tidak, karena kehendak bebas manusia bekerja dalam kedaulatan Allah. Dengan kata lain, di dalam kedaulatan-Nya, Allah memberikan manusia kehendak bebas. Kehendak bebas manusia ini hanya dapat beroperasi jika Allah mengizinkannya (kategori bersyarat). Allah tentu bisa saja menetapkan segala sesuatu dan tidak memberikan ruang sedikit pun bagi kehendak bebas manusia, namun Allah memilih untuk tidak melakukannya. Allah memilih untuk memberikan manusia kehendak bebas agar Ia dapat berelasi dengan manusia dengan relasi perjanjian dua arah. ${ }^{78}$ Dalam relasi inilah kebaikan, ketaatan, cinta, kasih, dan sukacita mendapatkan maknanya yang sejati dan bukan merupakan hasil dari ketetapan yang akan membuat nilai-nilai ini menjadi hambar dan tak berarti. Di sisi yang lain, konsep kedaulatan Allah seperti ini tidak mencederai karakter Allah yang mahakasih, mahaadil, dan mahakudus.

\section{Epilog: Dalam Rumah Bapaku Ada Banyak Kaum Injili ${ }^{79}$}

${ }^{77}$ C.S. Lewis, Kekristenan yang Asali, terj. Grace P. Christian (Bandung: Pionir Jaya, 2006), 81. Penekanan oleh penulis.

\footnotetext{
${ }^{78}$ Olson, Against Calvinisim, 101.

${ }^{79}$ Untuk judul epilog ini penulis berutang kepada Vanhoozer dan Treier, Theology and Mirror of Scripture, 19.
}

Klarifikasi telah disajikan, jelaslah bahwa Arminianisme menerima dan mengajarkan konsep kerusakan total dan keselamatan karena anugerah. Selain itu, penulis juga telah memaparkan masalah utama dari penolakan Arminianisme terhadap Calvinisme, yakni mengenai konsep kedaulatan Allah dalam Calvinisme yang deterministik membawa logika kepada Allah sebagai sumber dari segala dosa dan kejahatan. Oleh karena itu, Arminianisme merasa perlu untuk memberikan tanggapan terhadap konsep kedaulatan Allah menurut Calvinisme. Motifnya hanya satu, yakni menggaungkan kembali karakter Allah yang mahakasih, mahaadil, dan mahakudus, sesuai dengan ajaran Kitab Suci.

Di sisi yang lain, tentu sebagian teolog-teo$\log$ Calvinis tidak setuju jika dikatakan bahwa konsep kedaulatan Allah yang mereka percaya dan ajarkan membuat Allah menjadi sumber dari segala dosa dan kejahatan. Hal ini tentu bisa dimengerti dan diterima. Poin yang paling penting dari diskusi seperti ini adalah objektivitas dalam memaparkan teologi seseorang atau aliran tertentu dan keterbukaan hati untuk menerima adanya perbedaan dalam tubuh Kristus, khususnya dalam kalangan Injili. Kaum Injili harus dewasa dalam melihat perbedaan dan menerima yang berbeda sebagai saudara seiman dan bukan musuh yang harus disisihkan. Telah cukup lama sentimen dalam memberikan penekanan pada perbedaan berkembang dan menjalar dalam tubuh kaum Injili. Sudah cukup lama kaum Injili saling melempar stigma-stigma negatif. Padahal perbedaan seharusnya dilihat sebagai kekayaan.

Fakta bahwa kaum Injili terdiri dari beberapa tradisi yang berbeda (Menonit, Wesleyan, Arminian, Calvinis, Dispensasional, Teisme Terbuka, dan lain sebagainya) merupakan keragaman yang seharusnya dijaga dan dipelihara demi injil Kristus. ${ }^{80}$ Menerima perbedaan

${ }^{80}$ Sebagian teolog menolak untuk memasukkan Teisme Terbuka (Open Theism) sebagai kaum Injili. Misalnya, Bruce A. Ware, dengan lantang mengatakan bahwa, "My own view is that open theism is both wrong and damaging to faith in ways that cannot rightly be tolerated in the evangelical church" (Bruce A. Ware, Their God Is Too Small: 
tentu memberikan sumbangsih positif bagi intelektualitas kaum Injili dan terutama bagi pekabaran injil Kristus. Sedangkan sikap tertutup terhadap perbedaan akan berujung pada fundamentalisme kaku yang membuat sikap penuh curiga dan gampang menghakimi tumbuh subur, yang akhirnya bermuara pada perpecahan gereja. Mental kekanak-kanakan seperti ini harus ditinggalkan. Vanhoozer dan Treier memberikan nasihat yang baik, "While practicing the wisdom of particular traditions, together we pursue the fullest possible communion in gospel faith and collaboration in mission." " Prioritas kita adalah bagaimana kaum Injili bersatu dalam keragaman demi maksimalnya pemberitaan injil Kristus. Kaum Injili harus membiarkan metanarasi Allah (injil) menguasai berbagai narasi diskusi teologis sehingga kita tidak terjebak dalam sensasisensasi perdebatan yang tidak esensi. Dengan demikian, kaum Injili sebagai komunitas yang dibentuk oleh injil, menjadi saksi dan pembawa berita tentang injil Kristus bagi dunia yang terhilang. ${ }^{82}$ Soli Deo Gloria!

\section{DAFTAR KEPUSTAKAAN}

Abraham, William J. Aldersgate and Athens: John Wesley and the Foundation of Christian Belief. Waco: Baylor University Press, 2010.

Arminius, James. The Works of James Arminius. 2 vol. Diedit oleh Jon Van Hofwegen.

Open Theism and the Undermining of Confidence in God [Wheaton: Crossway, 2003], 8). Namun, seperti yang diketahui bersama bahwa sampai hari ini tidak pernah ada konsensus ekumenis untuk mendefinisikan makna atau arti dari kaum Injili. Menariknya, dari kebanyakan definisi atau ciri-ciri yang dipaparkan teolog-teolog Injili mengenai definisi kaum Injili, tidak satu pun kategori yang dilanggar oleh penganut Teisme Terbuka (misalnya, definisi Injili dalam The Cambridge Companion to Evangelical Theology, ed. Timothy Larsen dan Daniel J. Treier [Cambridge: Cambridge University Press, 2007], 1). Selain itu, penolakan Ware bersifat personal dan tidak mewakili Injili.

${ }^{81}$ Vanhoozer dan Treier, Theology and the Mirror of Scripture, 42.

${ }^{82}$ Bandingkan dengan Michael F. Bird, Evangelical Theology: A Biblical and Systematic Introduction (Grand Rapids: Zondervan, 2013), 699.
Grand Rapids: Christian Classics Ethreal Library, 2002.

Barclay, John M.G. Paul and the Gift. Grand Rapids: Eerdmans, 2015.

Bangs, Carl. "Arminius and the Reformation." Church History 30, no. 2 (Juni: 1961): 157.

- Arminius: A Study in the Dutch Reformation. Grand Rapids: Zondervan, 1985.

Bates, Matthew W. Salvation by Allegiance Alone: Rethinking Faith, Works, and the Gospel of Jesus the King. Grand Rapids: Baker Academic, 2017.

Bavinck, Herman. Reformed Dogmatics: Abridged in One Volume. Diedit oleh John Bolt. Grand Rapids: Baker Ademic, 2011.

Bird, Michael F. Evangelical Theology: A Biblical and Systematic Introduction. Grand Rapids: Zondervan, 2013.

Boice, James M. Whatever Happened to the Gospel of Grace?: Rediscovering the Doctrines that Shook the World. Wheaton: Crossway, 2001.

Calvin, John. Institutes of the Christian Religion. Diedit oleh John T. McNiell. Diterjemahkan oleh Ford L. Battles. Philadelphia: Westminster, 1959.

Cottrell, Jack W. "The Nature of the Divine Sovereignty." Dalam The Grace of God and the Will of Man: A Case for Arminianism, diedit oleh Clark H. Pinnock. Grand Rapids: Academic Books, 1989.

Craig, William Lane. "God Directs All Things: On Behalf of a Molinist View of Providence." Dalam Four Views on Divine Providence, diedit oleh Stanley N. Gundry dan Dennis W. Jowers. Grand Rapids, Zondervan, 2011.

\footnotetext{
Dalam Four Views on Divine Providence, diedit oleh Stanley N. Gundry dan Dennis W. Jowers. Grand Rapids, Zondervan, 2011.
} 
Enns, Paul. The Moody Handbook of Theology: Buku Pegangan Teologi 2. Diterjemahkan oleh Rahmiati Tanudjaja. Malang: Literatur SAAT, 2010.

Finney, Charles. Finney's Systematic Theology. Diedit oleh J.H. Fairchild. Minneapolis: Bethany Fellowship, 1976.

Forlines, F. Leroy. Classical Arminian: A Theology of Salvation. Nashville: Randall House, 2011.

Greathouse, William M. dan H. Ray Dunning. An Introduction to Wesleyan Theology. Kansas City: Beacon Hill, 1989.

Hart, David Bentley. The Doors of the Sea: Where Was God in the Tsunami?. Grand Rapids: Eerdmans, 2005.

Helm, Paul. "Classical Calvinist Doctrine of God." Dalam Perspectives on the Doctrine of God, diedit oleh Bruce A. Ware, 5-52. Nashville: B\&H Academic, 2008.

Horton, Michael S. The Christian Faith: A Systematic Theology for Pilgrims on the Way. Grand Rapids: Zondervan, 2011.

Jowers, Dennis W. "Introduction." Dalam Four Views on Divine Providence, diedit oleh Stanley N. Gundry dan Dennis W. Jowers, 7-24. Grand Rapids, Zondervan, 2011.

Larsen, Timothy dan Daniel J. Treier, ed. The Cambridge Companion to Evangelical Theology. Cambridge: Cambridge University Press, 2007.

Lewis, C.S. Kekristenan yang Asali. Diterjemahkan oleh Grace P. Christian. Bandung: Pionir Jaya, 2006.

Loftus, John W. Why I Became an Atheist: A Former Preacher Rejects Christianity. Amherst: Prometheus, 2012.

Marshall, I. Howard. "Predestination in the New Testament." Dalam Grace Unlimited, diedit oleh Clark H. Pinnock. Minneapolis: Bethany Fellowship, 1975.
McKim, Donald K., ed. Encyclopedia of the Reformed Faith. Louisville: WJK, 1992.

Muller, Richard. "Arminius and the Reformed Tradition." The Westminster Theological Journal 70, no. 1 (Spring, 2008): 40.

Olson, Roger E. The Story of Christian Theology: Twenty Centuries of Tradition and Reform. Downers Grove: IVP, 1999.

. Arminian Theology: Myths and Realities. Downers Grove: IVP, 2006.

- Against Calvinism (Grand Rapids: Zondervan, 2011), 74.

Packer, J.I. Penginjilan dan Kedaulatan Allah. Diterjemahkan oleh Helda Siahaan. Surabaya: Momentum, 2001.

Palmer, Edwin H. Lima Pokok Calvinisme. Diterjemahkan oleh Elsye. Surabaya: Momentum, 2011.

Peterson, Robert A. dan Michael D. Williams. Why I Am Not an Arminian. Downers Grove: IVP, 2004.

Picken, Stuart. Historical Dictionary of Calvinism. Lanham: Scarecrow, 2012.

Pinnock, Clark H., ed. Grace Unlimited. Minneapolis: Bethany Fellowship, 1975. ., ed. The Grace of God and the Will of Man: A Case for Arminianism. Grand Rapids: Academic Books, 1989.

Shelton, W. Brian. Prevenient Grace: God's Provision for Fallen Humanity. Anderson: Francis Asbury, 2014.

Sproul, R.C. Kaum Pilihan Allah. Diterjemahkan oleh Rahmiati Tanudjaja dan Jenny Wongka. Malang: Literatur SAAT, 2011.

Stanglin, Keith D. Arminius on the Assurance of Salvation: The Context, Roots, and Shape of the Leiden Debate, 1603-1609. Boston: Brill, 2007.

Thiessen, Henry C. Teologi Sistematika. Malang: Gandum Mas, 2010. 
Vanhoozer, Kevin J. Biblical Authority: Retrieving the Solas in the Spirit of Mere Christianity. Malang: Literatur SAAT, 2016.

Vanhoozer, Kevin J. dan Daniel J. Treier. Theology and the Mirror of Scripture: $A$ Mere Evangelical Account. London: Apollos, 2016.

Walls, Jerry L. dan Joseph R. Dongell. Why I Am Not A Calvinist. Downers Grove: IVP, 2004.
Ware, Bruce A. Their God Is Too Small: Open Theism and the Undermining of Confidence in God. Wheaton: Crossway, 2003.

ed. Perspectives on the Doctrine of God. Nashville: B\&H Academic, 2008.

Wesley, John. The Works of John Wesley. Vol 3. Diedit oleh Albert C. Outler. Nashville: Abingdon, 1986.

Williamson, G.I. Pengakuan Iman Westminster. Diterjemahkan oleh Irwan Tjulianto. Surabaya: Momentum, 2012. 